\title{
The Situated Meaning of Discourse in American Presidential Campaign Slogans: A Discourse Analysis Study
}

\author{
Asst.Lect. Hayder Hameed Githeeth, Asst.Lect. Dhurgham Mageed Abdzaid
}

DOI: $10.37648 /$ ijrssh.v10i04.037

Received:16 $6^{\text {th }}$ November, 2020; Accepted:10 ${ }^{\text {th }}$ December, 2020; Published: 14th December, 2020

\begin{abstract}
Slogans are short statements that are used by candidates in election campaigns. These statements are formed in a smart way to attract people's attention and persuade them to vote for. The study contains a number of slogans about different American presidents in different periods of time. The analysis of data has focused on three parts, the figured worlds, situated meaning and context. The study has reached out that the words in slogans have specific meanings according to specific contexts and this creates the figured world in audience's mind and convince them to vote for .

Key words : Slogan, Discourse, Situated meaning and Figured worlds .
\end{abstract}

\section{DISCOURSE ANALYSIS}

Discourse analysis is one of linguistics field that focuses on the way the language works to convey a number of social functions. It goes beyond the sentence and grasp the meaning of the message. Gee (2011:8) states that discourse analysis means the invstiagting of language use . This definition gives the main function of the language which is used in different contexts in daily life . Paltridge ( 2012 :2) adds that discourse analysis explains the patterns of any language in different kinds of texts and at the sametime shows the association between the language, social and cultural contexts where it is used. It is also takes into account the way of using language displays different sights about the world and the different understandings . It even shows how the use of language is affected by the relationship between participants . Furthermore, it shows how the views and identities are formed by the use of discourse.

Stubbs (1983:1) touches on the main functions of discourse analysis saying that ,firstly it is concentrated on using of language beyond sentence and utterance, secondly it is tackled with relationship between language and society and thirdly it is concerned with conversional characteristics of everyday communication . Paltridge ( Ibid) points out to the main interest of discourse analysis is that what the meanings and how these meanings are functioned in the language and this is the central area of discourse analysis .

\subsection{Discourse}

The meaning of discourse still varies among linguists and linguistic studies. However, there are attempts to determine the main concept of discourse. Johnstone (2008:2) observes that discourse is meant the real examples of communicative action in the means of language . Discourse, generally, is meaningful symbolic behavior ( Bloommaert, $2005: 2$ ) . Johnstone (2008:3) also claims that discourse is both as conceptions and ways of talking that influence and are influenced by the ideas . 
Widdowson(2011:5-7) notes the connection between the text and discourse in which all kinds of text are used to refer to something for some purposes . Accordingly, any stretch of language is a text. Still, we can label a notice or instruction as a text but we don't specify here the meaning of the text. Hence, it is common that the purpose of the text is to get message across or to express ideas or to get other people do certain things or to think in a certain way. Therefore, discourse underlies and motivates the production and the complexity of these communicative purposes mentioned like to make people do or think and so forth. As a result, discourse is considered as what any text producer means by a text and what a text meant to the receiver .Stubbs ( 1983:9) shows another way of distinguish between a text and discourse, a text is not interactive, whereas discourse is interactive. The definition that the study adapts is that discourse is employed to refer to the specific types of contexts of language use in this way it is like a genre or a kind of text . As a corollary, political discourse as a kind of language used in political context. In other words, a political slogan is the sort of language used in political contexts for political purposes .

\subsection{Context}

Context has a very important role in the meaning of sentence or words and even an utterance. Crystal ( 2003 : 104 ) notes that context refers to all features of nonlinguistic world related to the linguistic units that are used . Simultaneously, the word situation can be used in this sense resulting the compound noun is situational context . Put it in slightly different terms, situational context includes both the non-linguistic features and the awareness of speaker and hearer about what has been said earlier . Gee (2011: 6) maintains context as follows :

Context is a crucial term in discourse analysis ........ context includes the physical setting in which the communication takes place and everything in it, the bodies, eye gaze , gestures, and movements of the those present , what has previously been said and done by those involved in the communication, any shared knowledge those involved have, including shared cultural knowledge .

This definition gives us the main role of context in understanding of language in use. Therefore, political slogans have their context, it is the streets and the audience who are listening or chanting to the candidates and the places in which hold the time of speaking to politician' supporters .

\subsection{Figured Worlds}

Generally speaking, people have a number of stories about their life regarding various parts of things around them . These stories have a number of names like frames or figured worlds . Johnstone (2008:187-88) presents the term frame which is initiated by cognitive psychologists who are interested in modeling the knowing of a concept . Traditionally, a frame is a complex cognitive system connects together the attributes of any concept in a group of relations . Activating one node in this group will lead to activate the others just like the word driver might evoke the frame of car or vice versa.

Evans and Green (2006:222) asserts that " according to frame semantics, any word or grammatical structure is related with a frame that relates the entities and elements associated with a particular culturally embedded scene from human experience" .

Gee(2011:168-70) holds that the use of the words is not only based on their definitions or just their meaning , rather we use words based on theories, stories as well as models in our minds concerning what is typical and normal . These typical stories have been given different names as follows, folk theories, fames, scenarios, scripts , figured worlds and so on. At the same time, these stories differ for people by their social and culture group . Consequently, societies change, so what people take as typical can change and changes. Better in put, the figured worlds are dynamic and they have the sense of reformulating . Clearly, political slogans will play a key role in making the figured worlds in people's heads in the processes of election campaigns with helping of context.

\subsection{Political Communication}

Language is no longer as a means of saying something, but through language can human achieve and do a lot of things and messages. Therefore, language has relations in different science like politics. Hague et al (1998: 3-4) holds that politics has reconciling differences through talking and persuasion. As a result, communication is the main point to politics. Chilton(2004:6) says that any 
political activity doesn't exist without the use of language . Some activities or behaviors include especially physical coercion. On the contrary to that, doing of politics is mainly modeled by language . Namely, political communication involves language as a meanings of completing that any communication with other parties or with other groups of people to convince them as in slogans

Political communication takes many forms of contexts according to the nature of the text . The way of political posters or slogans are not the same as parliamentary debates . Lirola (2016:284 ) comments :

Choosing one political genre or another involves a change in the context that surrounds the text. For example, parliamentary debates normally take place in parliamentary buildings whereas political posters appear mainly in the streets, and people have to deconstruct the explicit or hidden meanings they display. Moreover, politicians speak directly in parliamentary debates whereas the political poster represents a politician who is not seen in person most of the time during the campaign.

\subsection{Slogans and Persuasion}

Slogans have very old roots in people social activities . They have been used in economics, politics and other different domains . Dynel (2009:204 ) verifies the origin of the word slogan that is derived from Gaelic term ( slaughghairm) means, battle-cry. This word was used in English in 1704 to refer to a sign or a proposition that distinguishes a particular group of people. The early use of slogans was as oral calls chanted verbatim because of their briefness and formal structure anchored in sound repetition and rhythm .

Crystal (2004:180) explains that slogans were used to refer to the battle -cry of Scottish can . But, now the use of slogans is not the same in which it is used as a form of a forceful-catchy, mind-grabbing utterance and so on . Political slogans can be defined in Wardhaugh's words
( 2006:119) as "a short statement about the reasons why candidates should be elected or why voters should vote for someone." Leech( 1966:276) shows the definition of slogan in advertisements as a short phrase when a company uses to marketing its own products by repetition . The main function of advertising slogan is to attract people' attention in a fast way like " Good food , Good life"

Virtanen and Halmari (2005:5 ) define persuasion as follows :

... persuasion is defined as those linguistic choices that aim at changing or affecting the behavior of others or strengthening the existing beliefs and behaviors of those who already agree, the beliefs and behaviors of persuaders included

This definition is related to the function of slogan in persuasive communication . Therefore , Beard (2000: 5758) says that all candidates use many ways of persuasion to make people vote for them . They use positive ones like producing themselves as a new product or negative ones like attacking other opponents. Still, in all these attempts language plays a key role of creating that influence to persuade people to vote for their candidates. Sequentially , slogans are used to sell products, then it is used by political parties as part of their persuasive tools.

\subsection{Situated Meaning}

Gee(2005:53) points out that the meaning words in their actual contexts are not general, rather they have specific meaning in in different contexts of use. Meaning is a complex concept, any word or structure in language has a certain "meaning potential," that is, a range of possible meanings that the word or structure can take on in different contexts of use. (Gee , 2011 : 151).

Gee ( $2011: 152$ ) gives the example of what the concept of situated meaning as follows

So words do not have just general meanings. They have different and specific meanings in different contexts in which they are used and in different specialist domains that recruit them. This is true of the most mundane cases. For instance, notice the change in meaning 
in the word "coffee" in the following utterances which refer to different situations: " The coffee spilled, go get the mop'" (coffee as liquid), "The coffee spilled, go get a broom" (coffee as grains), "The coffee spilled, stack it again", (coffee in cans). Or notice the quite different meanings of the word "work" in everyday life and in physics: e.g., I can say, in everyday life, that I worked hard to push the car, but if my efforts didn't move the car, I did no "work", in the physics sense of the word.

Therefore, situated meaning is a tool that is related to the fill in tool. This is in fact a part of what people fill in from the context . But it is a particularly crucial part of the filling in process. Words and phrases in actual contexts of use do not always have clear dictionary-like meanings. Listeners have to figure out-guess-what they mean based on what else has been said and other aspects of the context. So do we discourse analysts. Meaning-making is not a "look up" process. It is an active process ( Gee, 2011 : 153). We can apply this tool on studying the specific meaning of political slogans that are functioned to persuade people to vote for them .

\section{DATA ANALYSIS}

\subsection{Methods}

The study will analyze the discourse of slogans, especially American slogans during elections campaigns. The parts of the study includes the context of the slogans, the figured worlds and the situated meaning of the slogans . These three parts work together to build the sides of persuasion through language in slogans.

\subsection{Material}

The material of the study is about six slogans that are used during different times of the election campaigns. These slogans are only samples of the political slogan discourses . Therefore, the study suggests further studies in slogans in other countries and other election campaigns with more ideas .

\subsection{The Analysis of Slogans}

\section{Bill Clinton}

\section{Building a Bridge to the 21st Century}

The first slogan is about Clinton's election campaigns in 1996 . The slogan is here not just a text, rather it is a discourse. The concept of discourse has been found in this slogan through the interaction between the candidate Bill Clinton and his own audience who supports his presidency

The context is the time , 1996 and the situation of his campaign when he was speaking and repeating this slogan in front of his own audience .

The figured world is created here through the situated meaning of the word " Bridge ", The general meaning of the word bridge is known in a dictionary that refers to the something whether made by iron or wood to connect two sides. However, the specific meaning, here, is not that kind of bridge, it is in fact totally different . It is used here with meaning of a connector between two generations, or two times or it is used to make people move and relate their existence with a new time of development . The meaning is functioned according to the situation of the election campaign that poses such a kind of bridge , this bridge is not substantial, it is mental . As a result, the figured world that is created in this slogan is so attractive and it has a great impact on people's mind, they will think that this bridge connects them with a new life and a new change that they look for . Historically, Bill Clinton won in this election and became a president .

\section{Ronald Reagan}

\section{It's Morning Again in America}

The political slogan states what Reagan's campaign election is . This campaign was in election of 1984 , he won the election in highest ratio of voting .

The context of slogan was the time of carrying out the election campaign and the place is America. The audience was his own supporters who were listening to him . That time was important to America and the candidate Reagan should have chosen a slogan that makes his own campaign different . 
The figured world is the frame of what Reagan creates in his audience' mind. The word morning has a general meaning that refers to the beginning of a new day . But, the specific meaning is no doubt not the same. It was used to point out to the beginning of a new life in the life of America in various fields of life like economics, politics, education . This is very crucial in reminding people that the new beginning in America' life will be again in my agenda as a candidate. This figured world can't be created without the existence of the context that activates the choosing of right words in right election campaigns. The situation is that America needs new changes and new life , Reagan has chosen the word morning that has the sense of modern life and a good way of starting to build America

America Needs a Change - Walter Mondale in 1984

This presidential campaign slogan represents the political policy of the candidate, Walter Mondale. The slogan has a common word (change ). This word plays a key role in the whole campaign .

The context was in 1984 . The time and place of carrying out the campaign are really important . They contribute to the influence of the slogan, because the slogan itself can't be made without making a connection to the situation around the slogan .

Figured world is created in Mondale's mind through the word change .Generally, the word change refers to the meaning of moving from one state into another, but the word, in specific, is functioned to refer to the change of life in America according to the situation that urgently needs change. Therefore, the word change is used in slogan to create the specific concept of transforming in mind, this is very clear in the figured worlds .

\section{Let America be America Again - John Kerry in 2004}

The slogan maintains the concept retrieving back America . It was used in 2004 to state what America wants. The context is also the time and situation of that time. The general meaning of word America is common in a dictionary as a country . The figured world is that getting the developed America back is really influential because there is a time in the history of America was really developed. This is specific meaning of America that has been formed through the slogan. The specific meaning of the word America has all aspects of what America people want .

\section{Hope - Barack Obama in 2008}

Hope is used by in this slogan of president Barack Obama . The word is used in the context of that the president Obama belongs to the black people who represent the other part of the community . Hope is put in itself to create the specific meaning of starting and waiting new step in America . This figured world has been reformulated through the context in which people are looking forward to seeing America in a good position. Future and beginning a new step can't be formed through other words , except hope that has a deep root in people' spirit .

Make America great again - Donald Trump 2016

Trump uses this slogan to remind his people that we can make America better by our choice. The context in which Trump uses this slogan is the time of 2016 , that time America needs to have another situation. The chance of getting America back to the history will be very important after Obama's time. The figured world is functioned through connecting between what America wants and what America was. The specific meaning of the whole slogan is used in this concept of returning great, but not in general meaning of great. As a result, the specific meaning of great is the reforms that America needs in different fields like education, health, economics and so forth . Trump is, originally businessman , as a politician triggers the days that American people have in previous time and this enhances the trust and desire of voting for him .

\section{CONCLUSION}

The study has found out that words have both general and specific meanings. The specific meaning is produced by specific context in political domains. These meanings play an important role in building a certain kind of figured worlds . These figured worlds are held in slogans, for that reason candidates in elections choose the words that fit the political and social situation.

Slogan is a mean of creating persuasion. Hence, candidates put heavy focus on the way of the slogan that triggers the ideas and the policy that people need. They are not just a number of words, rather they are the containers of the message. The data shows how the words 
are chosen in slogans like morning, building, America and so on . There are other slogans with more imaginative and influential ideas which have been used to persuade

\section{BIBLIOGRAPHY}

people . The situated meaning is so clear, but it doesn't work a lone without context .

Paul , Baker ., and Sibonile, Ellece. 2011. Key Terms in Discourse Analysis . Continuum : New York .

Adrian ,Beard .2000. The Langauge of Politics . Routledge : New York .

Bloommaert , J . (2005). Discourse . Cambridge : Cambridge University Press .

Paul , Chilton. 2004. Analyzing Political Discourse . Routledge : London .

David, Crystal. 2003. A Dictionary of Linguistics and Phonetics . Blackwell : Oxford .

David, Crystal. 2004. The Cambridge Encyclopedia of the English Language. Cambridge: Cambridge University Press.

Marta, Dynel. 2009. Advances in Discourse Approaches . Cambridge Newcastle .

Vyvyan, Evans., and Melanie, Green. 2006. Cognitive Linguistics : An Introduction . Edinburgh: Edinburgh University Press

James, paul , G . (2005) . An Introdcuction to Discourse Analysis . Routledge : New york .

James, paul , G. (2011) . An Introduction to Discourse Analysis : Theory and Method . Routledge : New york .

James, paul , G. (2011) . How to do Discourse Analysis . Routledge : New york .

Rod , Hague ., Martin , Harrop ., and Shaun Breslin. 1998. Comparative Government and Politics : An Introduction , Basingstoke, Macmillan, $4^{\text {th }}$ edn.

BARBARA , JOHNSTONE . 2008 . Discourse Analysis . Blackwell : Oxford .

Geoffrey, N. Leech. 1966. English in Advertising. London: Longman.

Lirola , Martinez M." Multimodal analysis of a sample of political posters in Ireland during and after the Celtic Tiger" ISSN 0718 0934(2015), web 21 august .

Brain, Paltridge . (2012) . Discourse Analysis . Bloomsbury : London .

STUBBS Michael, 1983. Discourse Analysis: The Sociolinguistic Analysis of Natural Language. Oxford: Basil Blackwell.

Tuija Virtanen , T. and Helena H. (2005). " Persuasion across Genres " . (2005). Persuasion across Genres . John Benjamins : Philadelphia. . PP.5

Wardhaugh, Ronald . 2006. An Introduction to Sociolinguistics. Blackwell, London.

Henry G., Widdowson . 2011 . Discourse Analysis . Oxford : Oxford University Press . 